Estudios de

lingüística inglesa aplicada

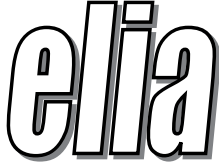

\title{
L1 ATTRITION'S STANCE WITHIN MULTICOMPETENCE: TRANSLINGUAL AND TRANS-SEMIOTIC FLOWS IN EDUCATIONAL CONTEXTS
}

\section{SITUACIÓN DE LA EROSIÓN DE LA L1 EN LA MULTICOMPETENCIA: FLUJOS DE TRANSLENJUAJE Y TRANS-SEMIÓTICOS EN CONTEXTOS EDUCATIVOS}

\section{Maite Amondarain Garrido}

Universidad Internacional de La Rioja, UNIR

maite.amondarain@unir.net

DOI: http://dx.doi.org/10.12795/elia.mon.2019.i1.07

All multilinguals are subjected to alteration in their L1 oral production, because they do not use it or due to the influence of other dominant languages. Besides, the language acquisition trajectory is featured by segregation, especially in educational contexts, where due to globalization, the foreign language is increasingly gaining relevance. This also provokes reservations about the danger of multilinguals not attaining adequate communicative skills in the L1. Moreover, the construction of meaning seems to be characterised by the interchange of different modes that flow in social intercommunication.

The present review of previous research on translanguaging and multimodality makes us comprehend the relationship between the two concepts within the multicompetence perspective. This describes language as a multisensory and multimodal semiotic system associated with other recognizable cognitive systems that cannot be separated. 
The concept of translanguaging suggests the integration of various languages in discourse. Furthermore, from the multicompetence perspective, the use of different languages is understood as an acculturation process. This fact, together with the impact of other languages on the L1, may underlie attrition. The supposition that multilingualism relates to the speakers' whole mind explains how development also occurs within their entire linguistic repertoire. Thus, translanguaging can be understood as a benefit for minoritised languages not isolating them from others.

The present study tries to shed light on how our translingual instinct as part of multimodality, within the multicompetence perspective, may endow the teaching and learning processes, and in particular L1 communicative skills, with the richness of the whole communicative repertoire.

Key words: L1 attrition, education, translanguaging, multimodality, multicompetence, multilingualism

Todo multilingüe está sujeto a cambios en la producción oral de su L1, por no utilizarla o por la influencia de otras lenguas dominantes. Además, la trayectoria de adquisición de lenguas se caracteriza por su aislamiento, sobre todo en contextos educativos, en los que la globalización potencia la importancia de la lengua extranjera. Esto provoca reservas ante el riesgo de que el multilingüe no adquiriera habilidades comunicativas adecuadas en la L1. Asimismo, la construcción de significado parece estar caracterizada por el intercambio de diferentes modos que fluyen en la intercomunicación social.

La presente revisión de investigaciones previas en translenguaje y multimodalidad nos lleva a la comprensión de su relación dentro de la perspectiva de multicompetencia. Ésta describe la lengua como un sistema semiótico multisensorial y multimodal asociado a otros sistemas cognitivos reconocibles e inseparables.

El concepto de translenguaje sugiere la integración de varias lenguas en el discurso. La multicompetencia asimismo entiende el uso de las diferentes lenguas como un proceso de aculturación. Esto unido al impacto de otras lenguas sobre la L1 podría subyacer a su erosión. El supuesto de que el multilingüismo se identifica con toda la mente explica cómo el desarrollo

ELIA Mon. I, pp. 155-178 DOI: http://dx.doi.org/10.12795/elia.mon.2019.i1.07 
también ocurre en la totalidad del repertorio lingüistico. Así, el translenguaje protege las lenguas minoritarias evitando su aislamiento.

Esta contribución trata de clarificar como nuestro instinto de translenguaje, parte de la multimodalidad, en la multicompetencia, puede enriquecer los procesos de enseñanza y aprendizaje, en particular las habilidades comunicativas de la L1, con la totalidad del repertorio comunicativo.

Palabras clave: Erosión lingüistica, Educación, Translenguaje, Multimodalidad, Multicompetencia, Multilingüismo

\section{Introduction}

Multilingualism is featured by its dynamic essence. Being multilingual involves immersion in a situation where constant choices are made from the speaker's linguistic and non-linguistic resources to attend to daily communication needs. Due to diverse reasons, the accuracy and rigour with which one's first language (L1) is deployed may decay - this is what we know as the language attrition process - or it may also be improved. In either case it seems that shuttling between languages and other non-linguistic resources is a common practice in multilingual societies. Many people inhabiting multilingual environments live through alteration in their L1, because it is not as easily accessible as it once was or due to its counteraction with a now closer and more significant language (Y1lmaz \& Schmid, 2018). On top of that, and despite curricular restraints, this heterogeneous discourse flows in multilingual classrooms all around the world. Translanguaging - flowing between languagesand trans-semiotising, - using all semiotic resources available for communication, either verbal or not- terms that define those flexible linguistic and non-linguistic communicative practices, seem to be sine qua non requirements that guarantee the changes in the individuals' output leading to claims that a loss or a development has occurred in the individuals' L1 (Wei, 2016a).

The aim of this study is to show how translanguaging as part of multimodality, within the multicompetence perspective, may facilitate the teaching and learning processes, and in particular L1 communicative skills and the decrease of L1 attrition, with the richness of the whole

ELIA Mon. I, pp. 155-178 DOI: http://dx.doi.org/10.12795/elia.mon.2019.i1.07 
communicative repertoire. Based on the purpose of the study, three operational hypothesis are addressed:

- Pedagogic translanguaging can be seen as either a strengthening or a risky language acquisition theory as regards L1 attrition.

- Classroom trans-semiotising might include the necessary practices for attaining a decrease in L1 attrition.

- A multicompetence perspective might be essential to understand L1 attrition in education, redefining it as a necessary process in language acquisition.

In so doing we aim at removing the negative connotation attached to the phenomenon known as L1 attrition and grounding educational theories, especially language teaching and learning within multilingual contexts, in a more flexible and functional manner.

The next section will therefore define L1 attrition by giving a simple example and stating some of the most relevant contributions as regards research on this phenomenon. The third section of this paper will deal with translanguaging and its influence on L1 attrition. Section four will describe multimodal practices in school contexts as beneficial to lessen L1 attrition. The multicompetence perspective and its impact on L1 attrition will be explained in section five. Finally, the article ends up with some conclusions about the transformation of the L1 in multilingual classrooms and the usefulness of multicompetence to understand it.

\section{Defining L1 Attrition}

It was after a term-meeting with some parents, when I was teaching English as a Foreign Language (EFL) and imparting Science modules, among other subjects, in a Basque Primary School (Spain), that one of my students' mothers, who had recently moved back with her family to the Basque Country after a long period of time living in Ireland, approached and explained that when speaking in Basque she had realized she had problems recalling some words, and got stuck while the English counterparts would appear in her memory. She went on by describing the way her Basque

ELIA Mon. I, pp. 155-178 DOI: http://dx.doi.org/10.12795/elia.mon.2019.i1.07 
language had deteriorated and that she kept repeating words or stopping her discourse in conversations where she happened to self-correct her own sentences or expressions once and again. On top of that, her relatives and friends had already let her know how strange her Basque accent was. She just wanted to ask me how she could help her kids with Basque if she seemingly needed to blow the dust off her native language first.

As Schmid (2011) points out, saying that this mother had nearly turned into a non-native of the culture she was born to is a bit exaggerated. Indeed, what this person was going through after such a long period of time abroad was a language attrition process. Seton and Schmid (2016, p. 338) define it as "the changes to linguistic skills or language proficiency under conditions of reduced use". Schmid and Köpke (2013, p. 2) suggest that it "is the outcome of two systems of linguistic knowledge interacting $[\ldots]$ in language processing during production and comprehension, and does not change the underlying knowledge system". In fact, in this mother's case the number of systems of linguistic knowledge interacting in her brain were three; she had always considered bilingual herself (Basque-Spanish) and late trilingual (English). As her native language had not vanished, she would soon gain confidence with mere usage and would be able to scaffold her kids.

Not being able to recall a language may occur in communities where native languages shift or die and can also happen in individuals, as in cases of pathological language loss, also referred to as aphasia. However, the expression language attrition alludes to a complete or incomplete language loss experienced by an individual in good condition. Besides, it is relevant to point out the ambiguous difference between incomplete L1 acquisition and L1 attrition. Research brings up the divergence between the kind of alteration that occurs before the linguistic system becomes stable (preceding adolescence) and attrition in adulthood (Schmid, 2011). Nonetheless, this paper will broadly refer to L1 attrition within children too.

Thus, language attrition can turn out to be very perceptible in migrants, like the mother in the example above, who had lived for a reasonable period of time under an L2-dominant condition (Schmid \& Köpke, 2007; Schmid 2011). In spite of the increasing number of migrant students and global mobility, L1 erosion is not bounded to such radical circumstances and hesitation may occur due to the creation of an

ELIA Mon. I, pp. 155-178 DOI: http://dx.doi.org/10.12795/elia.mon.2019.i1.07 
interlanguage system, or as the outcome of language-internal attrition patterns. Research on the position of disfluency markers within a sentence shows attriters' difficulties mainly when retrieving lexicon (Schmid \& Fägersten, 2010; Ribes \& Llanes, 2015). Few researchers, on the other hand, support that attriters produce a less complex version of their L1 (Ribes \& Llanes, 2015).

As Schmid (2013) argues, although attrition is not the straightforward result of how frequently the L1 has been used, its changing nature and irregular linguistic output can also be due to how an individual's languages have been acquired. Although how much has the L1 been used and how recent has that use of the $\mathrm{L} 1$ been can be an attrition prediction factor, they do not appear to be decisive in the L1's undermining or cross-linguistic influence (CLI). On the other hand, it seems that people who constantly need to use their L1 either professionally or in a formal way and, at the same time, need to prevent themselves from using their L2, display favourable outcomes as regards attrition. These speakers, such as for example teachers or professors, show better skills in avoiding the use of the L2 or have more experience doing it, and therefore their L1 output is not affected by their L2 or any other language (L3, L4 ... Ln) so easily. This would mean that the attrition level would not be as much determined by an underlying experience of the L1 as by the executive command of the speaker. Another factor that indicates favourable outcomes towards L1 attrition seems to be the attriters' adherence to their L1, this can also be decisive and show that a positive attitude towards the native language and culture would lead to less attrition.

Visible factors such as exposure to language, assertive disposition and high educative stance may contribute to protecting the L1, although more research is needed to definitely corroborate their influence on the maintenance of the native language (Y1lmaz \& Schmid, 2018). However, regardless of those factors that may predict language attrition appearance and those that might help maintaining the L1, one of the most relevant enrichment contributions that research into this phenomenon has made to comprehending multilingualism is the variability in language users' performance. Multilingual speakers' output is hence heterogeneous and shows an irregular structure, so it may be hard-pressed to organize it into a process of settled series of stages that match the ideal and standardized monolingual speaker (Seton \& Schmid, 2016). In fact, even "mature,

ELIA Mon. I, pp. 155-178 DOI: http://dx.doi.org/10.12795/elia.mon.2019.i1.07 
monolingual native speakers will usually not perform according to the 'target standard' one hundred per cent of the time" (Schmid, 2013, p. 117). Therefore, research on L1 attrition helps understand the evolving language interactions in complex multilingual and educational contexts. Furthermore, it shows the singularity of multilingual students' mental processes.

Speakers' expertise, intricacy, accuracy, eloquence, level of satisfaction, motivation, attitude and their mood towards the L1 vary and change over their lifetime and the same happens within their linguistic repertoire. This progress is restrained by numerous interwoven and fluctuating elements (Seton \& Schmid, 2016; Schmid, 2011). De Bot (2007) argues that relevant episodes that happen throughout life (e.g. going to a bilingual nursery, having a relative or friend abroad, attending a school with foreign languages included in the curriculum, going abroad to study, international exchanges, migration, etc.) may contribute to describing the way alterations within the diverse stages in a lifetime can produce linguistic variations that may influence language development. Moreover, he states that the Dynamic Systems Theory (DST), where the main aspects are sets of variables and variations in time, may help to explain L1 attrition, although the complicated nature of spoken language and the DST's conventions demand higher rigour as regards interaction and the role of variables within language development. In this respect, de Leeuw, Mennen and Scobbie (2013) state that DST steps back from considering language development as an unbending practice to describe it as an evolving process that understands acquisition and loss as part of it. On the whole, these authors call for an encompassing theory that combines L1 attrition research with discoveries done in other areas. According to Schmid (2013), while research into this changeable nature and the CLI of language learners' L2 or Foreign Language (FL) is well stablished, research into multilinguals' L1 is far from that position. Seton and Schmid (2016) state that there is a lack of studies that integrate both L1 attrition and L2 development in the same work and advocate that kind of research in order to make progress in our knowledge of multilingualism.

This claim becomes more reasonable indeed if we take into consideration the fact that even monolinguals have an idiolect, that is, the individuals' own language, nonpareil and belonging to the sole grammar in their minds that comes out when communicating with others and warrants language use (Otheguy, García \& Reid, 2015). This view is understood

ELIA Mon. I, pp. 155-178 DOI: http://dx.doi.org/10.12795/elia.mon.2019.i1.07 
from the internal position of the speaker as it shows the uniqueness of each individual's linguistic repertoire together with the intricacy of the relationship and competition of multilinguals' languages. Thus, in the following section the concept of translanguaging will be dealt regarding its appropriateness towards language attrition from an integral perspective. Translanguaging involves the use of the speakers' idiolect, that is, the use of their entire linguistic repertoire (Wei, 2018) which is otherwise usual, though not accepted neither standardised by a long chalk, in educative contexts.

\section{L1 Attrition in Translingual Classrooms}

The use of the individual's entire linguistic repertoire, despite not being legitimized by most school curricula, takes place in all multilingual contexts, even within classroom practices. Spontaneous translanguaging is commonplace in multilingual societies as well.

Multilingual and multicultural societies, where migration and mobility become widespread, need, more than ever before, an emphasis on inclusion and the promotion of education in values. In this regard, translanguaging breaks up with the man-made differences related to ideology that use labels in an attempt, perhaps, to make linguistic issues more comprehensible to humans. Thus, whilst languages are labelled as English, French, Chinese, Spanish or Basque and are referred to as minority, dominant, native, home, foreign or target, translanguaging overlooks such tags to focus on meaning-making (García, 2009; García \& Wei, 2014).

However, translanguaging is not just shifting between "linguistic structures, cognitive and semiotic systems and modalities, but going beyond them" (Wei, 2018, p. 23) and creating what Wei (2011) has called Translanguaging Spaces, which are social areas where individuals share their linguistic knowledge within their historical and experiential background to create identity and make meaning. Hence, this idea connects with that of "linguistic knowledge interacting" (Schmid \& Köpke, 2013, p. 2) stated above to explain language attrition. Additionally, this linguistic intercommunication brings together the concepts of creativity and criticality involved in multilingual practices. Multilingual students, engaged in those practices, use their imagination and capacity to create and their knowledge

ELIA Mon. I, pp. 155-178 DOI: http://dx.doi.org/10.12795/elia.mon.2019.i1.07 
to discuss by showing evidence of their reasoning. All this fits within current educational methodologies that foster team work, collaboration, critical thinking, etc. And these diverse multilingual practices, as Wei (2011) explicates, address stress, struggle, contention, disagreement, divergence and variation in multiple domains such as the ideological, political, historical and, quite conceivably, the linguistic one. But the widespread reticent use of the L1 in bilingual education holds up improvements when dealing with research and the reformulation of the potential function of L1 use. In this respect, Lin (2015), inspired by Halliday (1994), gathers the different purposes of L1 use accounted in the literature within three inter-related functions: Ideational functions, the ones that analyse meaning for the student; Textual functions, which show changes of themes or tasks within the lesson; and, Interpersonal functions, which negotiate social changes. Besides, this author describes CLIL (Content and Language Integrated Learning) as a suitable approach for both L1 and L2 planned use, when learning content.

Thus, it seems obvious that intercommunication and social interaction are prerequisites for the language attrition phenomenon. Furthermore, educational contexts appear to be propitious for L1 attrition to take place as L1 erosion, loss and decline, to a higher or lower extent, are unavoidable due to influence and competition between languages when efforts towards mastering an L2 are made. For that reason, the more two or all languages are used in a planned way, the better the communication skills of the speaker will be, consequently gradually reducing the effect of L1 attrition on oral production. We might then conclude that a CLIL setting within bilingual education like the one described by Lin (2015) can be eventually necessary to achieve a gradual decrease in L1 attrition due to the constant but crucial competition between languages within an approach where authenticity, dynamism and interaction are essential. Furthermore, research paradoxically shows that translanguaging can result advantageous in minoritised language contexts where attempts to support and enhance weaker languages awaken the fear of throwing overboard years of economic and personal investment in favour of their maintenance (Lewis, Jones \& Baker, 2012; Jones \& Lewis, 2014; Cenoz \& Gorter, 2017). It is not an overstatement to say that language attrition is not pleasantly envisaged in such minoritised educational contexts. Yet, Otheguy et al. (2015) state that the difficulty is not to care for an unadulterated and enclosed language that has been named Basque, Welsh or Cherokee, but ideally, the proper path is

ELIA Mon. I, pp. 155-178 DOI: http://dx.doi.org/10.12795/elia.mon.2019.i1.07 
directed towards a cultural-linguistic ensemble of diverse idiolects and translingual routines relevant for the society. Thus, Cenoz and Gorter (2017) propose some basic rules for sustainable translanguaging, such as: the creation of breathing spaces for minority language use (only the minority language is allowed); the use of minority languages within translingual routines (all linguistic repertoires are welcome together with the minority language); enhancing linguistic and metalinguistic sensibility by using new multilinguals' skills and by strengthening all languages; the improvement of a multilingual character; or linking instinctive and instructional translanguaging. In this respect and in line with previous reflections in the second section of this paper, didactic programming that considers pedagogical translanguaging and plans strategically the use of the different languages might foster the executive control of students. They therefore become aware of which language they are using and how and for which purpose they are using that language.

Translanguaging calls upon speakers to implement all their linguistic resources, both lexical and syntactic, independently, including and combining new resources and employing them openly and voluntarily, without hindrance, as part of their linguistic repertoire (Otheguy et al., 2015). Creese and Blackledge (2010) show how this flexibility within multilingual classrooms sets an adequate stage for an ecological approach to language teaching and learning, taking into account the already ascertained resources in conjunction with new ones; thus, observing the interactional aspect of social ideologies, as well as their creation and implementation. They suggest that as students get involved in flexible bilingualism, the limits between languages tend to dissipate. As Wei (2016a) clarifies, one of the outcomes of translanguaging is that there is no use in associating L1 and L2 acquisition in evaluative terms, regarding each one's level of attainment. Besides, translanguaging highlights the link between usual languages and other ways of communicating (Wei, 2018).

In this regard, Canagarajah (2011), takes over a critical stance to translanguaging theory and research for classroom purposes. He concludes that a practical decision would be the serious combination between existing conventions and the individual's own symbols and significance forever resulting in cautious negotiations, that is, sensibly negotiating meaning. In this sense, he states that multilinguals' education is multimodal because it encompasses optic and verbal semiotic resources. He also argues that since

ELIA Mon. I, pp. 155-178 DOI: http://dx.doi.org/10.12795/elia.mon.2019.i1.07 
students move beyond language and within spatial repertoires, tasks are the focal point and it is reasonable to understand how communication becomes clearer and more favourable. This spatial ecology shows language collaborating with assemblages of semiotic resources, man-made objects and background affordances in particular contexts to promote successful communication(Canagarajah, 2017). Therefore, pedagogic translanguaging can be considered a functional tool within classroom negotiation for meaning making that can help us understand that it might not only be the CLI but also a cross-semiotic influence (CSI) that, as has been argued, assertively underlies language attrition phenomenon.

Decisively, humans' innate gift to capitalize on various resources does not erode over time. Curiously for attriters, the skill of utilising many different ways of negotiating meaning is improved with experience (Wei, 2018). All this points to the adoption of multimodal approaches to analyse artefacts and social interactions (Jewitt, 2009). Thus, a close attention to multimodality seems fair to deepen the understanding of an apparently stereotyped view of language attrition in an educational setting.

\section{Furthering L1 Attrition to Multimodality in Education}

Translanguaging features the multisensory, multimodal, multi-semiotic and multilingual essence of communication and meaning construction that is influenced by the maxim of abundance (Wei, 2016a). This means that the more numerous and diverse the amount of modes, the easier communication will be. This also emphasizes the aforementioned idea of actual crosslinguistic and cross-semiotic influences towards language attrition.

Accordingly, people's language is interlinked with each other's bonds and with their social interplay, which holds historic, contextual, emotional and emblematic meanings connected with the human-made languages (Wei, 2018). This is even clearer in schoolchildren and youngsters whose attachment to their closest family members, teachers, professors and dearest mates, although in different degrees depending on the evolutionary stage they are, is really intense. It is not a matter of making material aspects, artefacts, and course of occurrences disappear, rather languaging involves the consideration of the socially-created languages complemented with experience, expression, cognition and semiotics (Lin,

ELIA Mon. I, pp. 155-178 DOI: http://dx.doi.org/10.12795/elia.mon.2019.i1.07 
2019). In this respect, Thibault (2017, p. 81) also underlines the way individuals "hear and feel voices and respond to dynamics [...] affect, feeling". Wei (2018) adopts and develops Pinker's (1994) language instinct analogy to highlight the prominence of current interactional negotiation, the multisensory and multimodal consideration of linguistic pedagogy and practice. What Wei (2018) calls Translingual Instinct influences language learning because the innate ability of mixing modes and all sorts of cognitive, semiotic and sensory resources makes learners count on the diverse means acquired or accessible throughout life. Consequently, as all these assets are not always evenly ready for use and beyond the inevitable CLI that features language attrition, the communicative interconnection at all levels among humans seems a natural occurrence between multilinguals and attriters.

Under these circumstances, a sociocultural juncture makes it possible to achieve a dilatory but presumably suitable shift in education. Current improvements in translanguaging and trans-semiotising reasoning might plausibly be influencing this fact. This process of thought revolves around knowledge construction and co-construction through communication, conversation, discussion, etc., and the driving flow of operating circumstances produced by translanguaging and trans-semiotising (Lin, 2019). All this adds a better perception of the essence of the teaching and learning process as a proactive course of events featured by multiple linguistic and non-linguistic resources. This view may help students disassemble genres, registers and styles of different disciplines and examine minutely the dynamic judgements, beliefs, suppositions and/or ideologies underpinning these canons. It is therefore urgent to develop meta-skills in multimodal design, re-design and register (Potts, 2017) so that students also learn to examine critically how these conventions have come into use and in what direction they might be emerging.

The notion of multiliteracies (New London Group, 1996) points to fluctuation in language use in consonance with a specific environment, such as the educational one. That notion originates from the expression multimodal literacy coined by Jewitt and Kress (2003) to stand for the intricacies of the different modes of meaning making. These authors explain that data and knowledge are built in multimodal texts and dissertations, which need multimodal literacy to entirely be grasped. Multimodal literacy aims at arranging speech by researching the enrichment

ELIA Mon. I, pp. 155-178 DOI: http://dx.doi.org/10.12795/elia.mon.2019.i1.07 
of particular semiotic resources (e.g. linguistic, gestural, pictorial) that are used transversely with diverse modalities (e.g. visual, acoustic, corporal), and their interplay and combination to build a logical text. Following Kress (2003) the proposal of moving from a linguistic to a multimodal literacy fits with the idea of improving students' ways of communicating. However, schools focus more on linguistic issues, how to express oneself linguistically, either in oral or written communication, not considering other ways to make meaning. Thus, maybe because the role of multimodal literacy is still a passive one due to a probable lack of awareness, Potts' (2017) points out that participation in the design of multimodal texts is needed, "developing the studied reflexivity to assess available designs and their potential for reassembling meaning" (p. 207). Learners can contribute to this evolving meaning making process for more equitable and inclusive purposes if they have a chance. They can also become more aware of what conventions they can use, in which settings, for what purposes, and with what probable outcomes (Lin, 2019).

Multimodal literacy can focus on improving students' critical reading by facilitating judgement and making them knowledgeable generators of multimodal texts by concentrating on the diverse meaningmaking means within the multimodal texts. As far as oral communication is concerned, not only voice tone and volume but also all sorts of somatic gestures and assertiveness or negativity of the discourse can be part of a multimodal literacy scheme. Besides, pupils can get to know how particular selected options match to attain motivated communicative objectives. Multimodality can be employed for learning languages and diverse subjects, such as science, given that many different modes for representing information are adopted to create learning in all fields (Fei, O'Halloran, Tan \& E., 2015).

Accordingly, spaces created in schools offer diverse possibilities. Home language, native language, L1 or mother tongue, no matter the way we call it, it is very much linked to the individuals' emotions due to the fact that it has been one of their main communicative tools since they were born and, therefore, it is an important part of students' linguistic repertoire. A flexible use of it in the classroom would enhance by all means students' creativity and fluency (Potts \& Moran, 2013). Thus, the construction of meaning seems to be featured by the interchange of different modes that flow and, unavoidably, exert mutual influence in

ELIA Mon. I, pp. 155-178 DOI: http://dx.doi.org/10.12795/elia.mon.2019.i1.07 
social intercommunication. In this regard, Kress, Jewitt, Ogborn, and Tsatsarelis (2014) show how each mode produces an incomplete meaning in isolation and interweaves with the others to generate the full meaning of the experience.

For Kress et al. (2014) the proof of the individuals' alteration in their reconfiguration of representational resources, such as the so-called languages plus all the different modes, is a result of the attainment of full awareness of some features of the world. It is the transformation in the apperception process and assimilation with actual assemblages of personal representations, and the rearrangement process that occurs when creating an original sign.

In this we take a reasonably strict approach to the concept of transformation, which entails the description of the initial structure(s) and a description of the structures which are the results of the processes of transformation, that is, a description of the structure of the new sign(s). Each aspect of the change in structures is seen as part of the remaking of signs and is therefore significant (Kress et al., 2014, p. 179).

Learning for these authors is the series of actions which are carried out in order to reshape the internal assemblages of representations that make the speaker or student, somehow, change. These actions aim identically at shaping again the internal and external resources and focus all the same on structuring anew the inner system (Kress et al., 2014).

Thus, at this point, the language attrition process might be seen as a necessary ingredient, as the indispensable part of the translingual and multimodal teaching and learning process. Therefore, by no means should classroom trans-semiotising be avoided, instead, as Van Leeuwen (2015) argues, we should probably turn the tables and use those aspects discovered from multimodality to describe linguistic communicative repertoires in new ways that motivate learners to improve their own linguistic repertoires. If this involves becoming an attriter, perhaps, it is time to start thinking of language attrition as a necessary part of the language acquisition process. Yet, interaction becomes essential to this commitment and as Wei (2016b) states, the idea of language in the Interactional Instinct theory is quite close to the thought stemmed from the multicompetence perspective of including diverse semiotic and cognitive processes.

ELIA Mon. I, pp. 155-178 DOI: http://dx.doi.org/10.12795/elia.mon.2019.i1.07 


\section{A Multicompetence Perspective to Understand L1 Attrition within Educational Contexts}

The working definition of multicompetence proposed by Cook (2016, p.1) describes multicompetence as "the overall system of a mind or a community that uses more than one language". This scholar also defines the L2 user as an individual that uses the foreign language for whatever reason, contrary to an L2 learner (Cook, 2016). Thus, it is when more than one language take part in the interplay and when the individual uses the foreign language, English as an L3 in the mum's former example, for living or for different goals, that we may describe the setting where multicompetence takes place. Indeed, following Cook's (1991) idea of bilingualism as cognitively involving multiple competences, senses and languages, investigation on language attrition has become more noticeable (Y1lmaz \& Schmid, 2018).

According to the former definition of multicompetence, Wei (2016a) poses a new thought conceived by the concept of language that redefines it as a semiotic arrangement of multiple senses and modes that, despite being integrated in that semiotic system, can be recognized even within additional individuals' cognitive influence over intercommunication.

The multicompetence perspective avoids counting the number of languages and focuses on the whole mind's multicompetence. It explores the diverse calculated and communicative functions of the different linguistic and non-linguistic resources freely used by the multilingual individuals in daily social interaction, such as the sort of communication found in educational contexts. Thus, the view of language from a multicompetent position is that of individuals' combination of multiple senses and modes together with cognition and semiotics to create thought and communicate ideas (Wei, 2016a). This is very common between students and increasingly updated within the collaborative and team-work tasks and projects frequently carried out nowadays at schools and universities where diverse competencies are valued. Therefore, there are no grounds for an evaluative comparison between the multi-competent language user and the monolingual native speaker. Moreover, in Schmid and Köpke's (2017a) words the cognitive demand for multilinguals when using language is bigger than that of monolinguals because the formers have to deal with a considerable amount of extra activities and difficulties, such as enduring interference or avoiding instinctive expressions from the

ELIA Mon. I, pp. 155-178 DOI: http://dx.doi.org/10.12795/elia.mon.2019.i1.07 
language not chosen to speak, in addition to the educational tasks that individuals already need to accomplish.

According to Cook's (2016) second definition of an L2 user, Wei (2016a) argues that a language cannot be forever mastered and that it is a dynamic aspect in each person's mind. Thus, the series of actions carried out by the individual when using a new language to be, somehow, fluent in it, involve an experience in which multiple senses and modes are being used. Hence, as long as the student makes use of language, then it makes more sense to think about language users that are constantly evolving their linguistic skills all over their lifetime, rather than just thinking about language learners. In this regard, any L1 attrition manifestation is featured as innate to multilinguals' maturation (Y1lmaz \& Schmid, 2018). Indeed, in such a pedagogical environment where students are encouraged to participate, to make choices and understand failure as part of the teaching and learning process, L1 attrition becomes even more meaningful. Accordingly, considering how students and language users make all sorts of choices to negotiatemeaning in intercommunication, the multicompetence perspective seems to have relevant involvement in L1 attrition research, expanding choice span with multimodality and all sorts of semiotic resources (Wei, 2016b).

Within this choice making process, multilinguals' distinct mental resources might ease the activation of those ideas related to language and, simultaneously, guarantee the activation of concepts that frequently have nothing to do with those previous thoughts. Concurrently, translanguaging or multilingual practices may enhance inhibition and systems that promote selective thought. In Kharkhurin's (2016) words, these systems might be relevant for thinking either in a divergent or in a convergent way, and therefore facilitate students' creative production. Moreover, evidence shows that cognitive plasticity, uncertainty threshold, willingness to experience new tasks, and motivation can be improved by multilingual or pedagogic translanguaging implementation. Multicompetence seems to contribute to the above personality attributes considering the management of languages by the student, the time of their acquisition, the conditions and degree of shuttling between languages, and the background in which language acquisition and use takes place. Thus, apparently, multicompetence not only fosters students' creative potential but also provides an adequate atmosphere for L1 attrition to disentangle.

ELIA Mon. I, pp. 155-178 DOI: http://dx.doi.org/10.12795/elia.mon.2019.i1.07 
However, L1 attrition effects in multilinguals are more noticeable in those cases where related particles or assemblages happen in the two languages, making easier a reciprocal transference. Thus, Schmid and Köpke (2017a) enquire about the underlying system within that two-sided transference, and examine the way in which L1 attrition phenomenon might be grasped by prevailing theoretical methods. In so doing, they claim that theories that study these multilingual transferences considering the L1 as rather unfluctuating, such as the Dynamic Systems Theory referred to above or the multicompetence dealt in this section, might be extended and validated with other theories that supplement and extend them by explaining the variations in the L1 while an L2 is being promoted. Thus, they deal with two actual L2 acquisition approaches: the Usage-based approach and the Generative one. Both agree on several aspects: the variation of the L1 within the multilingual brain; interaction being promoted due to the similarity between the L1 and the L2; the importance of exposure-rate; and, the relevance of the age of becoming multilingual (Schmid \& Köpke, 2017a).

These findings show the incessant variability, flow and adaptation of languages and the fact that similar factors that influence language acquisition might also be influencing the native language. Accordingly, the multicompetence perspective underlines the process of assimilation into a foreign culture, an acculturation process, that the multilingual undergoes when learning a language, where the seeming deficiency in achieving a target linguistic competency might be due to diverse reasons, of which non-linguistic ones are the bulk (Wei, 2016a). According to Seton and Schmid (2016), the process usually known as language attrition is intrinsic to the multicompetence perspective. And because the common discourse that takes place among students' interactions within didactic environments is featured by all these linguistic and non-linguistic semiotic resources and by a sort of concession to making mistakes, the multicompetence perspective becomes suitable to explain the multilingual practices happening in these contexts. Moreover, these scholars and Yilmaz and Schmid (2018) do not see the type of language used by attriters as a lowquality, simplified and eroded, type of speech; instead, they describe it as a mental process that happens under the influence of a greater language supersystem, together with a different language, probably the dominant one. Additionally, they also understand attriters' language as part of linguistic acquisition and multilingualism. Indeed, it was Grosjean (1989)

ELIA Mon. I, pp. 155-178 DOI: http://dx.doi.org/10.12795/elia.mon.2019.i1.07 
with his denial of the definition of bilingual as two monolinguals in one person, who triggered the series of actions that lead to understanding language attrition as a sole phenomenon that occurs as a result of the joint existence and the continuous interaction of two or more languages. As a result, many scholars (Cook, 2003; Grosjean, 2016; Kroll \& Fricke, 2014; Y1lmaz \& Schmid, 2018, among others) have argued that L1 attrition is an expected and reasonable phenomenon in multilinguals. Indeed, individuals that are able to communicate in more than one language have a linguistic supersystem (Cook, 2003) that shows the reciprocal influence between languages. Beyond the degree of that influence, all multilinguals might certainly be attriters (Schmid and Köpke, 2017b).

Thus, L1 attrition seems to be a natural process in multilingual educational settings and fits in the multicompetence perspective which, at the same time, redefines language attrition as a necessary process in language acquisition.

\section{Conclusion}

The multicompetence perspective shows a position of linguistic awareness where all linguistic features are simultaneously and reciprocally influenced and included in a larger supersystem. Research on language acquisition in multilingual contexts that thoughtfully considers the multicompetence perspective is not complete if the analysis only concerns the transformation of those languages that are non-native. In this regard, translanguaging, either spontaneous or pedagogic, should be considered as a useful classroom practice and as a relevant language acquisition theory considering L1 attrition.

This paper argues that, as struggle and competition, among other factors, between languages amongst multilingual speakers in school settings may lead to L1 attrition, a translingual perspective becomes essential to understand this phenomenon. Furthermore, and answering to the first operational hypothesis, pedagogic translanguaging may be seen as a strengthening language acquisition theory for explaining, comprehending and controlling L1 attrition by allowing a flexible use of languages in the class and protecting them in an enriching and diverse linguistic flow.

ELIA Mon. I, pp. 155-178 DOI: http://dx.doi.org/10.12795/elia.mon.2019.i1.07 
Moreover, it is also argued that far from avoiding classroom transsemiotising, the awareness of existing linguistic and non-linguistic resources should be fostered in students. This would make possible the necessary assemblages of practices for achieving an attenuation of L1 attrition levels and facilitate consistent meaning-making practices. This would lead to an improvement in communication and an enrichment of the teaching and learning process.

Therefore, claiming a multicompetence perspective becomes essential to understand L1 attrition in education. Because L1 attrition is thus redefined as a necessary and natural process in language acquisition. The presupposition that multilingual progress relates to the individual's entire psyche, not just his or her L1 or L2, sets forth improvements and transformations that happen in the L1 while a different language is being internalized or deployed on an equivalent level, with the maturation of the language that is being learnt. Although the transformation undergone by the L1 is scarcely contemplated in current linguistic research.

Meanwhile, probably a reconceptualization of the term, a more practical, essential and assertive view of language attrition as part of the communicative flow and language acquisition, needs to be developed and expanded in multilingual educational contexts to better analyse more realistic classroom practices.

\section{References}

Canagarajah, S. (2011). Translanguaging in the classroom: Emerging issues for research and pedagogy. Applied linguistics review 2, 1-28. https://doi. org/10.1515/9783110239331.1

Canagarajah, S. (2017). Translingual Practice as Spatial Repertoires: Expanding the Paradigm beyond Structuralist Orientations. Applied Linguistics, 39(1), 31-54. https://doi.org/10.1093/applin/amx041

Cenoz, J., \& Gorter, D. (2017). Minority languages and sustainable translanguaging: threat or opportunity? Journal of Multilingual and Multicultural Development, 38(10), 901-902. https://doi.org/10.1080/01434632.2017.12 84855

ELIA Mon. I, pp. 155-178 DOI: http://dx.doi.org/10.12795/elia.mon.2019.i1.07 
Cook, V. (1991). The poverty-of-the-stimulus argument and multi-competence. Second Language Research, 7(2), 103-117. https://doi. org/10.1177/026765839100700203

Cook, V. (Ed.) (2003). Effects of the second language on the first. Clevedon: Multilingual Matters.

Cook, V. (2016). Premises of multi-competence. In V. Cook \& L. Wei (Eds.), The Cambridge Handbook of Linguistic Multi-competence (pp. 1-25). Cambridge: Cambridge University Press.

Cook, V., \& Wei, L. (2016). The Cambridge Handbook of Linguistic Multicompetence. Cambridge: Cambridge University Press.

Creese, A., \& Blackledge, A. (2010). Translanguaging in the bilingual classroom: A pedagogy for learning and teaching? The Modern Language Journal, 94(1), 103-115. https://doi.org/10.1111/j.1540-4781.2009.00986.x

de Bot, K. (2007). Dynamic systems theory, lifespan development and language attrition. In B. Köpke, M. S. Schmid, M. Keijzer \& S. Dostert (Eds.), Language attrition: Theoretical perspectives (pp. 1-8). Amsterdam/ Philadelphia: John Benjamins.

de Leeuw, E., Mennen, I. and Scobbie, J. M. (2013). Dynamic systems, maturational constraints, and L1 phonetic attrition. International Journal of Bilingualism, 17(6), 683-700. https://doi.org/10.1177/1367006912454620

Fei, V.L., O'Halloran, K., Tan, S., \& E, M. (2015). Teaching visual texts with the multimodal analysis software. Educational Technology Research and Development, 63(6), 915-935. https://doi.org/10.1007/s11423-015-9395-4

García, O. (2009). Bilingual Education in the 21 $1^{\text {st }}$ Century: A Global Perspective. Malden, MA: Wiley-Blackwell.

García, O., \& Wei, L. (2014). Translanguaging: language, bilingualism and education. New York: Palgrave Macmillan.

Grosjean, F. (1989). Neurolinguists, beware! The bilingual is not two monolinguals in one person. Brain and Language 36(1), 3-15.

Grosjean, F. (2016). The Complementarity Principle and its impact on processing, acquisition and dominance. In C. Silva corvalán \& J. Treffers-Daller (Eds.),

ELIA Mon. I, pp. 155-178 DOI: http://dx.doi.org/10.12795/elia.mon.2019.i1.07 
Language dominance in bilinguals: Issues of measurement and operationalization (pp. 36-65). Cambridge: Cambridge University Press.

Halliday, M. A. K. (1994). An introduction to functional grammar. London: Edward Arnold.

Jewitt, C. (2009). The Routledge handbook of multimodal analysis. New York/ London: Routledge.

Jewitt, C., \& Kress, G. (Eds.). (2003). Multimodal literacy. New York: Peter Lang.

Jones, B., \& Lewis, G. (2014). Language arrangements Within Bilingual Education in Wales. In E. M. Thomas \& I. Mennen (Eds.), Advances in the Study of Bilingualism (pp. 141-170). Bristol: Multilingual Matters.

Kharkhurin, A. V. (2016). Multi-competence as a creative act: ramifications of the multi-competence paradigm for creativity research and creativity-fostering education. In V. Cook \& L. Wei (Eds.), The Cambridge Handbook of Linguistic Multi-competence (pp. 420-444). Cambridge: Cambridge University Press.

Kress, G. (2003). Literacy in the new media age. London: Routledge.

Kress G., Jewitt, C., Ogborn, J., \& Tsatsarelis, C. (2014). Multimodal teaching and learning: The rhetorics of the science classroom (2nd ed.). New York: Bloomsbury Academic.

Kroll, J. F., \& Fricke, M. (2014). What bilinguals do with language that changes their minds and their brains. Applied Psycholinguistics, 35(5), 921-925. https://doi.org/10.1017/S0142716414000253

Lewis, G., Jones, B., \& Baker, C. (2012). Translanguaging: Origins and Development from School to Street and Beyond. Educational Research and Evaluation: An International Journal on Theory and Practice, 18(7), 641-654. https://doi.org/10.1080/13803611.2012.718488

Lin, A. M. Y. (2015). Conceptualising the potential role of L1 in CLIL. Language, Culture and Curriculum, 28(1), 74-89. https://doi.org/10.1080/07908318.2 014.1000926

Lin, A. M. Y. (2019). Theories of trans/languaging and trans-semiotizing: implications for content-based education classrooms. International Journal

ELIA Mon. I, pp. 155-178 DOI: http://dx.doi.org/10.12795/elia.mon.2019.i1.07 
of Bilingual Education and Bilingualism, 22(1), 5-16. https://doi.org/10.10 80/13670050.2018.1515175

Otheguy, R., García, O., \& Reid, W. (2015). Clarifying translanguaging and deconstructing named languages: A perspective from linguistics. Applied LinguisticsReview, 6(3),281-307.https://doi.org/10.1515/applirev-2015-0014

Pinker, S. (1994). The Language Instinct. William Morrow and Company.

Potts, D. (2017). Critical Praxis, Design and Reflection Literacy: A Lesson in Multimodality. In R. Harman (Ed.), Bilingual Learners and Social Equity Critical Approaches to Systemic Functional Linguistics (pp. 201-223). Cham: Springer.

Potts, D., \& Moran, M. J. (2013). Mediating multilingual children's language resources. Language and Education, 27(5), 451-468. https://doi.org/10.10 80/09500782.2012.720688

Ribes, Y., \& Llanes, À. (2015). First language attrition: The effects of acculturation to the host culture. Procedia - Social and Behavioral Sciences 173, 181 185. https://doi.org/10.1016/j.sbspro.2015.02.050

Schmid, M. S. (2011). Language Attrition. Cambridge: Cambridge University Press.

Schmid, M. S. (2013). First Language Attrition. WIRE's Cognitive Science, 4(2), 117-123. https://doi.org/10.1002/wcs. 1218

Schmid, M. S., \& Fägersten, K. B. (2010) Disfluency Markers in L1 Attrition. Language Learning, 60(4), 753-791. https://doi. org/10.1111/j.1467-9922.2010.00575.x

Schmid, M. S., \& Köpke, B. (2007). Bilingualism and attrition. In B. Köpke, M. S. Schmid, M. Keijzer \& S. Dostert (Eds.), Language attrition: Theoretical perspectives (pp. 1-8). Amsterdam/Philadelphia: John Benjamins.

Schmid, M. S., \& Köpke, B. (2013). First Language Attrition. In M. S. Schmid \& B. Köpke (Eds.), Language Attrition. Theoretical perspectives (pp. 1-5). Amsterdan/Philadelphia: John Benjamins Publishing Company.

Schmid, M. S., \& Köpke, B. (2017a). Epistemological keynote paper with commentaries. Epistemological keynote paper with commentaries.

ELIA Mon. I, pp. 155-178 DOI: http://dx.doi.org/10.12795/elia.mon.2019.i1.07 
Linguistic Approaches to Bilingualism, 7(6), 637-667. https://doi. org/10.1075/lab.17058.sch

Schmid, M. S., \& Köpke, B. (2017b). When is a bilingual an attriter? Response to the commentaries. Linguistic Approaches to Bilingualism 7(6), 637-667. https://doi.org/10.1075/lab.17059

Seton, B., \& Schmid, M. S. (2016). Language attrition and multicompetence. In V. Cook \& L. Wei (Eds.), The Cambridge Handbook of Linguistic Multi-competence (pp. 338-354). Cambridge: Cambridge University Press.

The New London Group. (1996). A pedagogy of multiliteracies: Designing social futures. Harvard Educational Review, 66(1), 60-92. https://doi. org/10.17763/haer.66.1.17370n67v22j160u

Thibault, P. J. (2017). The reflexivity of human languaging and Nigel Love's two orders of language. Language Sciences, 61, 74-85. https://doi.org/10.1016/j. langsci.2016.09.014

Van Leeuwen, T. (2015) Multimodality in education: some directions and some questions. Tesol Quarterly, 49(3), 582-589. https://doi.org/10.1002/ tesq. 242

Wei, L. (2011). Moment analysis and translanguaging space: Discursive construction of identities by multilingual Chinese youth in Britain. Journal of Pragmatics, 43(5), 1222 - 1235.

https://doi.org/10.1016/j.pragma.2010.07.035

Wei, L. (2016a). Epilogue: Multi-competence and the Translanguaging Instinct. In V. Cook \& L. Wei (Eds.), The Cambridge Handbook of Linguistic Multi-competence (pp. 533-543). Cambridge: Cambridge University Press.

Wei, L. (2016b). Consequences of multi-competence for sociolinguistic research. In V. Cook \& L. Wei (Eds.), The Cambridge Handbook of Linguistic Multi-competence (pp. 164-182). Cambridge: Cambridge University Press.

Wei, L. (2018). Translanguaging as a Practical Theory of Language. Applied linguistics, 39(1), 9-30. https://doi.org/10.1093/applin/amx039

ELIA Mon. I, pp. 155-178 DOI: http://dx.doi.org/10.12795/elia.mon.2019.i1.07 
Y1lmaz, G. \& Schmid, M. S. (2018). First language attrition and bilingualism: Adult speakers. In D. Miller, F. Bayram, J. Rothman \& L. Serratrice (Eds.), Bilingual Cognition and Language: The state of the science across its subfields (pp. 225-250). Amsterdam/Philadelphia: John Benjamins.

First version received: July, 2019 Final version accepted: November, 2019

ELIA Mon. I, pp. 155-178 DOI: http://dx.doi.org/10.12795/elia.mon.2019.i1.07 